\title{
EPSA17: Selected papers from the biannual conference in Exeter
}

\author{
Thomas A. C. Reydon ${ }^{1} \cdot$ David Teira $^{2} \cdot$ Adam Toon $^{3}$
}

Received: 31 May 2018 / Accepted: 1 August 2018 / Published online: 3 October 2018

(C) Springer Nature B.V. 2018

The sixth international conference of the European Philosophy of Science Association (EPSA) took place at the University of Exeter on 6-9 September 2017. The conference included contributed papers, symposia, and a poster session, covering 10 topical areas: General philosophy of science; Philosophy of the physical sciences; Philosophy of the life sciences; Philosophy of the cognitive sciences; Philosophy of the social sciences; Philosophy of technology and philosophy of interdisciplinary research; Philosophy of science in practice; Formal philosophy of science; Integrated history, philosophy, and social studies of science; and Ethical issues in the sciences. To broaden the scope of the conference beyond the topical areas that are typically represented in conferences (general philosophy of science and the philosophies of the various special sciences) this conference included topical sections with special focus on ethics, technology and interdisciplinarity, scientific practice, and integrated HPS. While

This article belongs to the Topical Collection: EPSA17: Selected papers from the biannual conference in Exeter Guest Editors: Thomas Reydon, David Teira, Adam Toon

Thomas A. C. Reydon

reydon@ww.uni-hannover.de

David Teira

dteira@fsof.uned.es

Adam Toon

a.toon@exeter.ac.uk

1 Institute of Philosophy \& Centre for Ethics and Law in the Life Sciences (CELLS), Leibniz Universität Hannover, Im Moore 21, 30167 Hannover, Germany

2 Departamento de Logica, Historia y Filosofia de la ciencia, UNED, Senda del rey 7, 28040 Madrid, Spain

3 Department of Sociology, Philosophy and Anthropology \& Centre for the Study of Life Sciences (Egenis), University of Exeter, Byrne House, St. German's Road, Exeter EX4 4PJ, UK 
it is impossible to adequately represent the whole diversity of the field, as organizers we believed that including these topical areas would give the conference a high degree of inclusivity with respect to the topics and approaches that are currently pursued in the philosophy of science.

We received a total of 467 submissions, 424 of which were contributed papers, 36 symposia, and 7 posters. While the number of submitted contributed papers and symposia constituted clear increases from previous EPSA conferences, the number of submitted posters unfortunately was quite low. Submissions were received from authors from 48 countries. A total of 198 slots in 6 parallel sessions were available for talks, in which both the contributed talks and the symposium talks had to be accommodated, such that the Program Committee had to be highly selective, and many excellent papers unfortunately could not be accepted as talks on the program. All submissions were peerreviewed by members of the Program Committee.

Of the 424 contributed papers that were received, 142 were accepted as talks (yielding an acceptance rate of about 33\%), and of the received 36 symposia 14 were accepted (yielding an acceptance rate of 39\%). As the number of slots for talks was quite limited and we wanted to allow as many members as possible of the philosophy of science community to be able to participate in the conference, the call for papers included an option for authors of contributed papers to have their submissions considered for a poster presentation in case the paper could not be accepted as a contributed talk, but still was judged to be of sufficient quality to be acceptable for the conference. One hundred fifty-eight authors of contributed papers chose this option, and 23 papers of them were accepted as posters instead of talks. This substantially increased the number of posters in the poster session.

The present virtual special issue collects selected papers from the conference. Rather than producing the conference proceedings in the form of an edited book or special journal issue, for the 2017 meeting the board of the EPSA, in consultation with the Editors in Chief of the EJPS and the chairs of the Program Committee and the Local Organizing Committee, decided to try out a new format for the conference proceedings - a virtual proceedings issue. We invited all of the contributing authors to EPSA17 to submit their papers to the EJPS through a dedicated conference track. The submissions have been treated as regular submissions, with the chairs of the Program Committee and Local Organizing Committee acting as guest editors. The papers have gone through a conventional peer review process and, upon acceptance, have been published as self-standing articles in regular issues of the journal. With all the published EPSA17 papers, the journal's publisher, Springer, has agreed to create a virtual issue gathering them all on a dedicated website. We expected authors to find a good journal with a quick publication schedule a more attractive option than an edited book. And indeed, despite a late announcement, within 6 months we received 42 submissions (out of 198 conference presentations). The review process is still ongoing, as we publish this introduction together with the first accepted paper. We hope that this virtual proceedings will yield a higher impact for the ideas discussed at EPSA17. 
We would like to end by thanking the members of the Program Committee ${ }^{1}$ and the Local Organizing Committee ${ }^{2}$ for their hard work to make EPSA2017 possible. We also want to thank the Editors in Chief of the EJPS and Ties Nijssen and the Springer team for their cooperation in launching this virtual issue.

\footnotetext{
${ }^{1}$ The Program Committee was chaired by David Teira and Thomas Reydon, and consisted of: Anna Alexandrova, Atocha Aliseda, Sorin Bangu, Anouk Barberousse, Claus Beisbart, Robyn Bluhm, Alisa Bokulich, Seamus Bradley, Karim Bschir, Martin Carrier, Hasok Chang, Richard Dawid, Silvia de Bianchi, Helen de Cruz, Frédérique de Vignemont, Catarina Dutilh-Novaes, Melinda Fagan, Miguel Garcia-Sancho, Sara Green, Francesco Guala, Catherine Herfeld, Wybo Houkes, Paul Hoyningen-Huene, Lena Kästner, Marie I. Kaiser, Daniel Kostic, Jouni-Matti Kuukanen, Aki Lehtinen, Olimpia Lombardi, Miles MacLeod, James McAllister, Marcin Milkowski, Fred Muller, Antigone Nounou, Thomas Potthast, Hans Radder, Gabor Szabo, Davide Vecchi, Pieter Vermaas, Niki Vermeulen, Jon Williamson, Charles Wolfe, Julie Zahle.

${ }^{2}$ The Local Organizing Committee was chaired by Adam Toon, and consisted of: Sabina Leonelli (Deputy Chair), John Dupré, Shane Glackin, Staffan Müller-Wille.
} 